
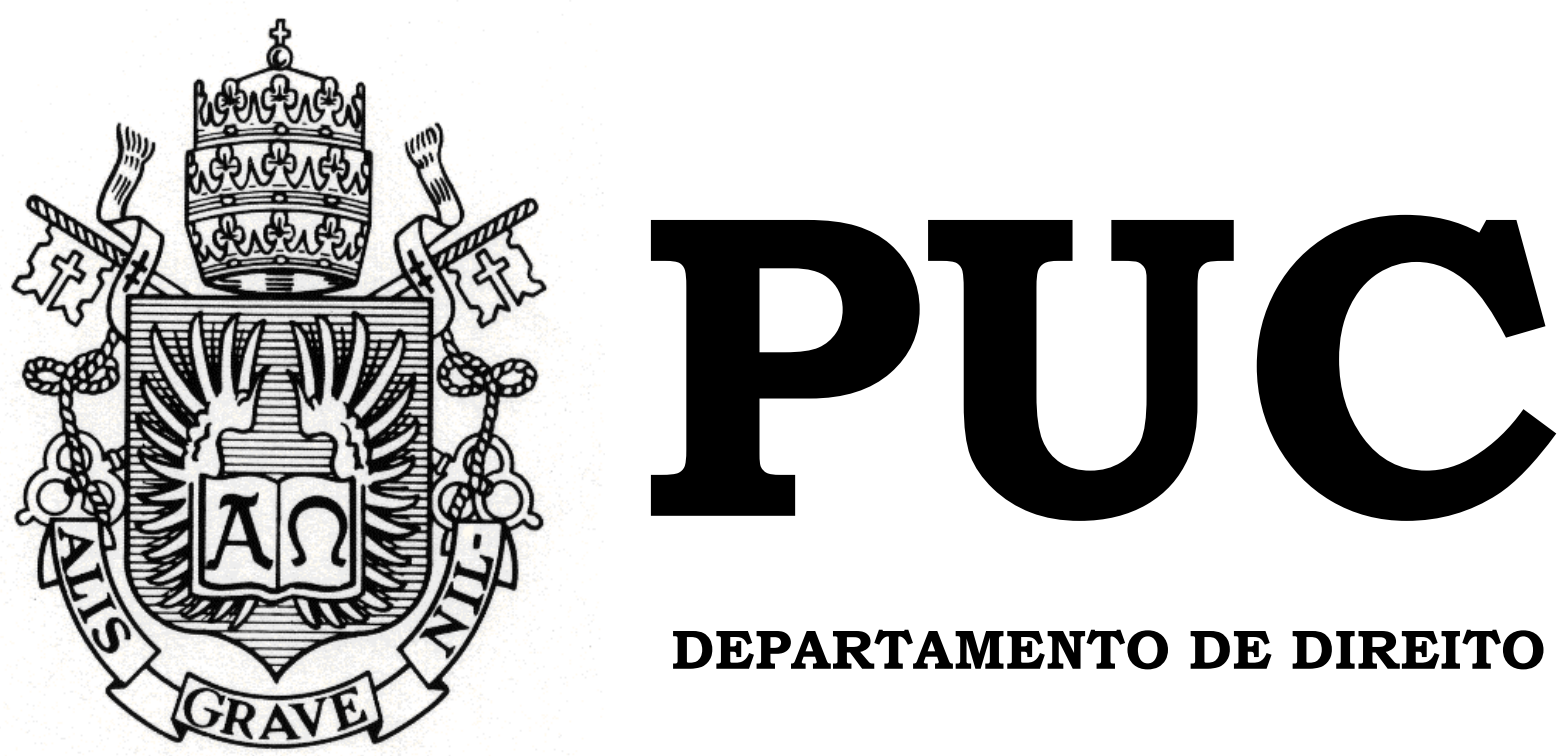

DEPARTAMENTO DE DIREITO

\title{
O REGIME DISCIPLINAR DIFERENCIADO E O DIREITO PENAL DO INIMIGO
}

\section{Por}

\section{ALICE DE LEMOS MACCACCHERO}

\section{ORIENTADORA: VICTÓRIA SULÓCKI} 2017.2

PONTIFÍCIA UNIVERSIDADE CATÓLICA DO RIO DE JANEIRO RUA MARQUÊS DE SÃO VICENTE, 225 - CEP 22451-900 RIO DE JANEIRO - BRASIL 


\section{O REGIME DISCIPLINAR DIFERENCIADO E O DIREITO PENAL DO INIMIGO}

por

\section{ALICE DE LEMOS MACCACCHERO}

Monografia apresentada ao

Departamento de Direito da

Pontificia Universidade Católica do Rio de Janeiro (PUC-Rio) para a obtenção do Título de Bacharel em Direito.

Orientadora: Victória Sulócki 
Mesmo que os castigos cruéis não se opusessem diretamente ao bem público e ao fim que se lhes atribui, o de impedir os crimes, bastará provar que essa crueldade é inútil, para que se deva considerá-la, como odiosa, revoltante, contrária a toda justiça e à própria natureza do contrato social" Cesare Beccaria (1764) 


\section{AGRADECIMENTOS}

Aos meus pais, Mônica e Tullio pelo apoio incondicional nesta trajetória e por nunca terem se negado a me oferecer os melhores colégios, cursos e faculdade. Tenho a total certeza de que sem vocês nada disso seria possível! Cada livro comprado, cada "puxão de orelha", cada "Alice, como você foi nas provas? ", me fizeram sempre querer superar cada erro, cada dificuldade ao longo deste percurso. Obrigada. Sem vocês, eu nada seria.

Ao meu namorado Daniel por todo o companheirismo, por ter suportado as minhas grosserias nas vésperas das provas, por ter sido paciente com os meus choros e inseguranças, por ter me dado todo o suporte que precisei ao longo dos últimos anos, que não foram fáceis. Enfim, por ser a melhor pessoa que eu poderia escolher para conviver durante os próximos anos da minha vida. Te amo muito.

Ao bebê que estou gerando, por ser a minha maior alegria diária desde que fiquei sabendo que o estava esperando. Essa monografia é, sobretudo, em homenagem a ele, pois como aplicadora do direito e futura concursada não se pode deixar de pensar em um direito processual penal mais justo e isonômico.

Aos meus irmãos Marina, Raphael e Daniel por terem acreditado na minha competência e por sempre quererem me fazer crescer ao longo desses 27 anos de convivência.

Ao meu cunhado, Matheus e ao Instituto Carioca de Criminologia por ter emprestado todas as bibliografias a que fiz referência nesta monografia e por terem engrandecido os debates acerca de tão complicado tema.

Aos meus tios João e Lígia, bem como meus primos Adriana e Fábio por todo o suporte familiar e por todo o carinho com a prima/sobrinha caçula.

Aos meus padrinhos Hiroshi e Ângela por todo o amor e o carinho despendido a mim desde que eu era bebê. 
Aos meus sogros Eunice e Leônidas, bem como a minha avó do coração Dona Normélia, por terem me apoiado e cedido espaço em sua casa para que eu pudesse estudar e descansar, uma vez que ir de Pendotiba para o Rio nunca foi um trajeto fácil.

As minhas eternas companheiras do Galdino, Coelho e Mendes Advogados, Maria Eduarda Gamborgi, Michelle Goes e Giulia Pesce, por sempre me apoiarem e acreditarem no meu potencial. Levo cada uma para vida com enorme carinho e amor.

Aos meus amigos e amigas da PUC-Rio Luciano Krsnamurti, Nicolle Moura, Ana Beatriz Chaves, Thiago Varella, Débora Sol, Ana Luísa Borgongino, Adriana Puccini e Alice Catão por terem me acolhido e por me aceitarem como amiga, ainda que no final da faculdade. Sem vocês, eu não teria tido tanta força e paciência para seguir em frente nesses dois últimos anos.

A minha orientadora Victória Sulócki por ter me aceitado como sua orientanda e pela paciência ao longo desses árduos meses de incessantes escritas. 


\section{RESUMO}

O presente trabalho visa promover uma análise sobre a tese defendida pelo doutrinador Günther Jakobs acerca do Direito Penal do Inimigo e o Regime Disciplinar Diferenciado. Para tanto, será pontuada diversas celeumas ainda incutidas no sistema prisional brasileiro, a primeira delas de violação à dignidade da pessoa humana, uma vez que o regime disciplinar diferenciado não pode ser considerado um castigo, mas sim uma nova modalidade de tortura psicológica e corporal. Por fim, critica-se a ideia de um direito penal do inimigo, como fruto de um estado que repudia do estado democrático de direito e todos os seus corolários.

Palavras Chaves: Direito Penal. Princípio da Dignidade da Pessoa Humana. Vedação à Tortura. Governo de Exceção. Execução Penal. Regime Disciplinar Diferenciado. Direito Penal do Autor. 


\section{SUMÁRIO}

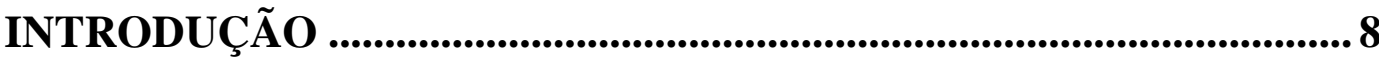

CAPÍTULO 1 - O PRINCÍPIO DA DIGNIDADE DA PESSOA

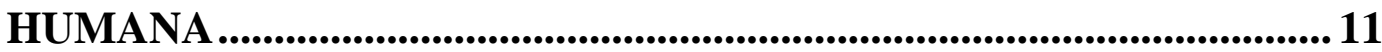

1.1. O Princípio da Dignidade da Pessoa Humana no Processo Penal ... 13

1.2. O Princípio da Dignidade da Pessoa Humana como ensejador da vedação à tortura .................................................................................... 15

CAPÍTULO 2 - O REGIME DISCIPLINAR DIFERENCIADO ......... 19

2.1. Breve Histórico da Lei de Execuções Penais..................................... 19

2.2. Regime Disciplinar Diferenciado.................................................... 23

2.3. A Obscuridade na Previsão Legal do Artigo 52 da Lei de Execuções Penais

CAPÍTULO 3 - O REGIME DISCIPLINAR DIFERENCIADO COMO EFEITO DO DIREITO PENAL DO INIMIGO..........................36 CAPÍTULO 4 - CRÍTICAS À IDEIA DE UM DIREITO PENAL DO

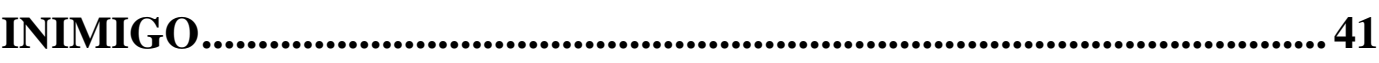

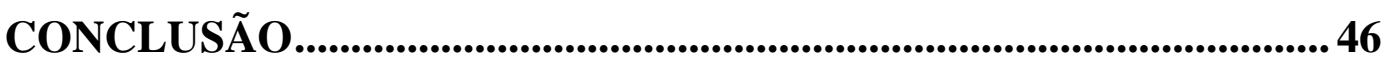

REFERÊNCIAS BIBLIOGRÁFICAS .................................................51 


\section{ABREVIAÇÕES}

Art. - artigo

CF - Constituição Federal de 1988

CP - Código Penal

P. - página

STF - Supremo Tribunal Federal

STJ - Superior Tribunal de Justiça

TJRJ - Tribunal de Justiça do Estado do Rio de Janeiro 


\section{INTRODUÇÃO}

Inicia-se o referido trabalho com a abordagem acerca da dignidade da pessoa humana no contexto do sistema prisional. É cediço que o referido princípio é o sustentáculo da ordem jurídica vigente, contudo no que diz respeito ao tratamento dispensado ao preso dentro das unidades penitenciárias, seja no que se refere à estrutura física, seja no que se refere à estrutura profissional, há um contumaz desrespeito a esse corolário.

Impende salientar que, a origem desse regime é anterior à referida lei. Isto porque, em maio de 2001, a Secretária de Administração Penitenciária do Estado de São Paulo editou a resolução de número 26, na qual instituiu o sobredito regime disciplinar; após a grande rebelião ocorrida no Estado pelo PCC; em 2003, o Estado do Rio de Janeiro, também efetua o regime disciplinar especial, seguindo o exemplo do Estado de São Paulo.

Sobrevém que, essas medidas administrativas sofreram grandes críticas com a sua implementação e, a lei 10.792/03 veio apenas para legitimar, o que já era praticado em dois grandes estados do Brasil: Rio de Janeiro e São Paulo.

$\mathrm{O}$ referido trabalho, para tanto, tem a finalidade de discutir e discorrer sobre o regime disciplinar especial a partir de uma visão da criminologia e do direito processual penal. Dessa forma, início este trabalho final de curso com um dos principais pilares de um Estado Democrático de Direito, qual seja ele: a dignidade da pessoa humana no contexto do sistema prisional brasileiro.

É cediço que este corolário de toda a ordem jurídica vigente no Brasil, vem sendo manifestamente desrespeitado, mormente no que tange ao tratamento dispensado ao preso dentro das unidades prisionais, que não possuem, em sua grande maioria, estrutura correspondente ao pleno atendimento da dignidade da pessoa humana, seja no âmbito da estrutura, seja no âmbito da própria qualificação de seus profissionais. 
Será, portanto, nessa perspectiva de insatisfação geral, tanto da população carcerária quanto do restante da sociedade, que se sente desprotegida e vulnerável diante do aumento dos índices violência, é que irá emergir o regime disciplinar diferenciado, como uma forma de "resposta" à população e, por outro lado, como uma forma de contenção dos indivíduos considerados perigosos para a coletividade. Com isso, recrudescem-se as penas e seus métodos de execução, a fim de atender aos anseios de uma parcela privilegiada da sociedade.

Oportuno, ainda, dizer que, em paralelo à discussão do sistema carcerário brasileiro, aborda-se a teoria do direito penal do inimigo, a qual é fruto de um trabalho do penalista germânico Günter Jakobs e que tem ganhado grande reconhecimento, bem como adeptos.

A sobredita doutrina traz em seu bojo a existência de determinados indivíduos os quais não devem ser classificados como "pessoas", e que, com isso, não poderiam vir a gozar das garantias oferecidas pelo Estado. Seriam estes, portanto, grandes criminosos, terroristas, homens-bomba e etc.

$\mathrm{Na}$ tentativa de determinar quem seriam os inimigos da sociedade brasileira, o trabalho traz a ideia de periculosidade e desenvolve junto a ela o conceito e os fundamentos do direito penal do inimigo.

Além disso, o trabalho também faz uma análise do conceito de précrime, intrínseco ao direito penal do inimigo, e que encontra previsão legal no artigo 52 na Lei de Execuções Penais cujo objetivo é definir os parâmetros de aplicação do regime disciplinar especial.

No que tange às críticas do i. Doutrinador Eugenio Raul Zaffaroni à ideia do também doutrinador Günther Jakobs, o trabalho tenta demonstrar que a polaridade entre amigo-inimigo gera a existência de uma guerra permanente, sendo que tal beligerância é fundamental para criar um estado de paz.

Indispensável, ainda, dizer que, além destes, o objetivo geral traçado para o estudo deste tema foi a contextualização do regime disciplinar 
diferenciado e a sua implementação à hodierna crise pela qual passa o sistema carcerário brasileiro, delineando, portanto, o que tem a ver o referido instituto e o direito penal do inimigo.

Posto isto, os objetivos basilares desta pesquisa, consistiram em analisar o conceito e a natureza jurídica do regime disciplinar diferenciado, as imprecisões terminológicas trazidas pela lei que o positivou no ordenamento jurídico brasileiro, além de demonstrar as suas raízes históricas, as quais demonstram as verdadeiras motivações para o seu surgimento.

Cabe dizer também que não podemos deixar de mencionar outro objetivo fundamental deste trabalho de conclusão de curso: traçar a similitude entre o regime disciplinar e o direito penal do inimigo.

Portanto, neste trabalho procurei conceituar os institutos supramencionados, com a finalidade de fazer uma análise bem detalhada do regime disciplinar diferenciado positivado pela Lei número 10.792/03, como uma consequência do direito penal do inimigo. 


\section{CAPÍTULO 1 - O PRINCÍPIO DA DIGNIDADE DA PESSOA HUMANA}

$A b$ initio, é no cristianismo que surgem as primeiras preocupações com a dignidade da pessoa humana, pois se o homem foi criado à imagem e semelhança de Deus, deveria ser reconhecido como um valor fundamental em si mesmo.

Contudo, será a partir do iluminismo que a noção de dignidade da pessoa humana começa a ganhar força mais racional, e, assim, irradiar seus efeitos na ordem jurídica. Seguindo essa linha de raciocínio, o Estado passa a ser criado para assegurar a dignidade de seus cidadãos e não o contrário.

No Brasil, após a constituinte de 1988, verifica-se que o princípio da dignidade da pessoa humana tem a função de integrar o ordenamento jurídico constitucional, com o intuito de dar reconhecimento aos direitos fundamentais, bem como ser "o epicentro axiológico da ordem constitucional". ${ }^{1}$

Nesse sentido, a carta brasileira o coloca como um dos fundamentos da República Federativa do Brasil e o afasta do rol dos direitos fundamentais, previstos no art. $5^{\circ}$ da carta constitucional. Tal deslocamento propositado, demonstra ser esse o princípio que possui a maior carga valorativa e hierárquica de todos os outros princípios reconhecidos no ordenamento brasileiro, com isso, "os direitos fundamentais constituem explicitações da dignidade da pessoa humana" 2

Nas palavras do i. doutrinador Luis Gustavo Grandinetti:

A Constituição brasileira o enumerou entre os princípios fundamentais da República e não como direito fundamental do art. $5^{\circ}$. Isso não quer dizer que, segundo a óptica orgânica, o princípio

\footnotetext{
${ }^{1}$ SARMENTO, Daniel A. A ponderação de interesses na Constituição Federal. $1^{\mathrm{a}}$ ed. Rio de Janeiro: Lumen Juris, 2002, p. 59.

${ }^{2}$ SARLET, Ingo Wolf. Dignidade da Pessoa Humana e direitos fundamentais na Constituição Federal. $2^{\mathrm{a}}$ ed. Porto Alegre: Livraria do Advogado, 2002, p. 60.
} 
não seja um direito fundamental: ele é um direito fundamental, mas, além disso, é um dos fundamentos do Estado brasileiro. ${ }^{3}$

É valido, ainda, destacar que não existe direito absoluto, pois, se por um lado há a ampla atuação do princípio da dignidade da pessoa humana - sem qualquer limite -, por outro, nega-se a vigência dos demais direitos. Desse modo, deve o princípio ser ponderado no caso concreto, ao se colidir com outros valores constitucionais.

Parte-se do pressuposto de que a dignidade da pessoa humana é um direito constitucional positivo, o qual possui dupla natureza: a de princípio e a de regra. Ao se tratar de um princípio, é passível, mesmo em situações excepcionais, de ponderação com outros princípios e bens jurídicosconstitucionais.

Contudo, ao se tratar de uma regra, averígua-se em diversos casos que a dignidade da pessoa humana veda determinada conduta ou até mesmo impõe uma determinada ação. Nessa seara, a dignidade da pessoa humana assume a feição absoluta, uma vez que obsta a possibilidade de ponderação junto ao critério da proporcionalidade.

Por fim, é incontroverso o fato de que ao responder a uma ação penal, há a restrição da dignidade do réu; as próprias determinações legais do processo penal têm esse efeito: mandado de busca e apreensão domiciliar, ser preso, e etc., demonstra-se, portanto, não ser intocável a dignidade da pessoa humana, apenas o seu núcleo essencial.

\footnotetext{
${ }^{3}$ CARVAlHo, Luis Gustavo Grandinetti Castanho de. Processo Penal e Constituição. Princípios
} Constitucionais do Processo Penal. 6a ed. São Paulo: Saraiva, 2014, p. 57. 


\subsection{O Princípio da Dignidade da Pessoa Humana no Processo Penal}

O desenrolar da história do processo penal apresenta três sistemas de processos bastante díspares entres si, quais sejam: o acusatório, o inquisitivo e o misto.

O sistema acusatório se configura por partir em três as funções de acusar, defender e julgar, outorgando o poder desses atos processuais a três pessoas: promotor de justiça, nos casos de ação penal pública, defensor público ou advogado e juiz.

Além disso, dá maior publicidade aos feitos, bem como dá a possibilidade de contraditório, com o maior grau de isenção do magistrado na condução do procedimento.

Por outro lado, o sistema inquisitivo, sendo o oposto do sistema mencionado acima, se caracteriza pelo sigilo dos atos processuais, pela concentração dos procedimentos de acusar e julgar na figura do juiz.

Ademais, inexiste o contraditório e o sistema de provas era o ordálico, o qual autorizava a tortura como meio legal de prova e a confissão era considerada prova absoluta do fato.

Por fim, havia ampla participação do magistrado na obtenção de provas, de modo que, ao julgar, já não havia sinal de imparcialidade, a qual é indispensável à função de julgar.

O sistema misto aproveita características do sistema inquisitivo e acusatório, em fases distintas do processo, ou seja, a persecução penal é inquisitiva na fase de inquérito e acusatória na fase processual propriamente dita.

É oportuno destacar que, em determinado momento da História, pensadores de ciências distintas tais quais a jurídica, política e filosófica começaram a construir sustentáculos para instrumentalizar reações ao totalitarismo jurídico e político da Idade Média, o que deu oportunidade à 
concepção da ideia segundo a qual o réu tem o direito inafastável de exercer a sua defesa de forma ampla e regulada em lei.

Contudo, a evolução do direito processual penal não se estabilizou neste momento. Isso porque, não bastava somente o reconhecimento da dignidade à pessoa do réu, mas também era necessário conceder eficácia a esses preceitos por meio de mecanismos processuais ensejadores do exercício eficaz de defesa.

Somente a partir do século XIX, por intermédio das obras de Wach, e, sobretudo, de Bulow é que se deu início à teorização do surgimento de um processo cuja relação com o réu era a de seu reconhecimento como sujeito de direito, com deveres, faculdades e ônus processuais, assim como já ocorria com a parte autora.

O mérito dessa teorização está consubstanciado, s.m.j.:

No reconhecimento de que o réu deixou definitivamente de ser objeto do processo para ser sujeito da relação processual, titular de direitos e faculdades processuais, apto a exercê-los em igualdade de condições em relação ao autor da demanda, além dos deveres e ônus que sempre teve. ${ }^{4}$

Nesse sentido, estão intimamente ligados entre si o princípio da dignidade, o sistema acusatório e a concepção do processo como relação jurídica, de modo que, todos esses preceitos - em conjunto - configuram os direitos processuais do acusado.

Outrossim, ainda se encontram consagrados no princípio constitucional da dignidade, outras garantias processuais enumeradas ao longo do rol do art. $5^{\circ}$ da Constituição da República Federativa do Brasil: o contraditório, a ampla defesa, a isonomia e etc.

Notoriamente percebe-se a ocorrência da constitucionalização de um sistema processual penal que traga em seu bojo a garantia da preservação das

\footnotetext{
${ }^{4}$ Ibid, p. 59.
} 
características fundamentais do sistema acusatório, bem como a concepção do processo como relação processual.

Conforme preleciona Luis Gustavo Grandinetti:

Está assegurado constitucionalmente, pelo princípio da dignidade, um direito processual que confia ao acusado o direito a ser julgado de forma legal e justa, um direito a provar, contraprovar, alegar e defender-se de forma ampla, em processo público, com igualdade de tratamento em relação à outra parte da relação processual, bem como que a gestão da prova não seja deferida ao julgador, sob pena de retorno ao sistema inquisitivo. ${ }^{5}$

Conclui-se que, a inconstitucionalidade diante da carta constitucional de 1988 estaria na opção de um sistema processual penal, no qual o polo passivo da relação processual retornasse ao status de mero espectador da instrução penal, mas não só isso, como também do julgamento. Dessa forma, está demonstrada a efetividade do princípio da dignidade da pessoa humana.

\subsection{O Princípio da Dignidade da Pessoa Humana como ensejador da vedação à tortura}

Conforme lecionado em capítulo anterior, o princípio da dignidade da pessoa humana assume tanto a característica de regra quanto a de princípio, sendo possível, neste último, fazer a ponderação, a depender do caso concreto, da limitação ou não de sua eficácia.

Nessa seara, a questão mais emblemática está na vedação à prática de tortura. No Brasil, por inteligência do art. $5^{\circ}$, inciso III da CFRB de 1988, o suplício da tortura é vedado, pois, além de ser uma norma específica de direito fundamental, é também tratada como norma proibitiva de determinada conduta.

À guisa desse entendimento, Luis Gustavo Grandinetti preleciona que:

\footnotetext{
${ }^{5}$ Ibid, p. 60.
} 
$\mathrm{O}$ art. $5^{\circ}$, III, da Constituição enuncia uma regra que consagra um direito fundamental: a proibição da tortura. Se, por um lado, o princípio da dignidade não é absoluto, como se sustentou acima, permitindo algumas restrições em seu campo de proteção, por outro aspecto, a Constituição gravou um núcleo mínimo, essencial, instransponível, que não pode ser ultrapassado. ${ }^{6}$

A referida prática implica necessariamente na coisificação e na degradação da pessoa, a qual acaba por ser transformada em objeto de ação arbitrária de terceiros, o que é incompatível com a dignidade da pessoa e consequentemente com a regra nuclear da proteção da dignidade da pessoa humana. Não se trata a tortura, neste caso, de princípio, mas de regra.

Convém registrar, no contexto, que já é pacífico e reiterado o posicionamento do Supremo Tribunal Federal no sentido de ratificar a proibição absoluta da tortura, como no caso do precedente no Habeas Corpus $\mathrm{n}^{\mathrm{o}} 70.389 / \mathrm{SP}$, in verbis:

TORTURA CONTRA CRIANÇA OU ADOLESCENTE EXISTÊNCIA JURÍDICA DESSE CRIME NO DIREITO PENAL POSITIVO BRASILEIRO - NECESSIDADE DE SUA REPRESSÃO CONVENÇÕES INTERNACIONAIS SUBSCRITAS PELO BRASIL PREVISÃO TÍPICA CONSTANTE DO ESTATUTO DA CRIANÇA E DO ADOLESCENTE (LEI No 8.069/90, ART. 233)- CONFIRMAÇÃO DA CONSTITUCIONALIDADE DESSA NORMA DE TIPIFICAÇÃO PENAL - DELITO IMPUTADO A POLICIAIS MILITARES INFRAÇÃO PENAL QUE NÃO SE QUALIFICA COMO CRIME MILITAR - COMPETÊNCIA DA JUSTIÇA COMUM DO ESTADOMEMBRO - PEDIDO DEFERIDO EM PARTE. PREVISÃO LEGAL DO CRIME DE TORTURA CONTRA CRIANÇA OU ADOLESCENTE - OBSERVÂNCIA DO POSTULADO CONSTITUCIONAL DA TIPICIDADE. - O crime de tortura, desde que praticado contra criança ou adolescente, constitui entidade delituosa autônoma cuja previsão típica encontra fundamento jurídico no art. 233 da Lei $\mathrm{n}^{\circ}$ 8.069/90. Trata-se de preceito normativo que encerra tipo penal aberto suscetível de integração pelo magistrado, eis que o delito de tortura - por comportar formas múltiplas de execução - caracteriza- se pela inflição de tormentos e suplícios que exasperam, na dimensão física, moral ou psíquica em que se projetam os seus efeitos, o sofrimento da vítima por atos de desnecessária, abusiva e inaceitável crueldade . - A norma inscrita no art. 233 da Lei ${ }^{\circ}{ }^{8}$ 8.069/90, ao definir o

\footnotetext{
${ }^{6}$ Ibid, p. 71.
} 
crime de tortura contra a criança e o adolescente, ajusta-se, com extrema fidelidade, ao princípio constitucional da tipicidade dos delitos (CF, art. $5^{\circ}$, XXXIX). A TORTURA COMO PRÁTICA INACEITÁVEL DE OFENSA À DIGNIDADE DA PESSOA. A simples referência normativa à tortura, constante da descrição típica consubstanciada no art. 233 do Estatuto da Criança e do Adolescente, exterioriza um universo conceitual impregnado de noções com que o senso comum e o sentimento de decência das pessoas identificam as condutas aviltantes que traduzem, na concreção de sua prática, o gesto ominoso de ofensa à dignidade da pessoa humana. A tortura constitui a negação arbitrária dos direitos humanos, pois reflete - enquanto prática ilegítima, imoral e abusiva - um inaceitável ensaio de atuação estatal tendente a asfixiar e, até mesmo, a suprimir a dignidade, a autonomia e a liberdade com que o indivíduo foi dotado, de maneira indisponível, pelo ordenamento positivo. NECESSIDADE DE REPRESSÃO À TORTURA CONVENÇÕES INTERNACIONAIS . - O Brasil, ao tipificar o crime de tortura contra crianças ou adolescentes, revelou-se fiel aos compromissos que assumiu na ordem internacional, especialmente àqueles decorrentes da Convenção de Nova York sobre os Direitos da Criança (1990), da Convenção contra a Tortura adotada pela Assembléia Geral da ONU (1984), da Convenção Interamericana contra a Tortura concluída em Cartagena (1985) e da Convenção Americana sobre Direitos Humanos (Pacto de São José da Costa Rica), formulada no âmbito da OEA (1969). Mais do que isso, o legislador brasileiro, ao conferir expressão típica a essa modalidade de infração delituosa, deu aplicação efetiva ao texto da Constituição Federal que impõe ao Poder Público a obrigação de proteger os menores contra toda a forma de violência, crueldade e opressão (art. 227, caput, in fine). TORTURA CONTRA MENOR PRATICADA POR POLICIAL MILITAR COMPETÊNCIA DA JUSTIÇA COMUM DO ESTADO-MEMBRO. O policial militar que, a pretexto de exercer atividade de repressão criminal em nome do Estado, inflige, mediante desempenho funcional abusivo, danos físicos a menor eventualmente sujeito ao seu poder de coerção, valendo-se desse meio executivo para intimidá-lo e coagi-lo à confissão de determinado delito, pratica, inequivocamente, o crime de tortura, tal como tipificado pelo art. 233 do Estatuto da Criança e do Adolescente, expondo-se, em função desse comportamento arbitrário, a todas as consequiências jurídicas que de correm da Lei $n^{\circ}$ 8.072/90 (art. $2^{\circ}$ ), editada com fundamento no art. $5^{\circ}$, XLIII, da Constituição . - O crime de tortura contra criança ou adolescente, cuja prática absorve o delito de lesões corporais leves, submete-se à competência da Justiça comum do Estado-membro, eis que esse ilícito penal, por não guardar correspondência típica com qualquer dos comportamentos previstos pelo Código Penal Militar, refoge à esfera de atribuições da Justiça Militar estadual. $^{7}$

\footnotetext{
7 STF - HC: 70389 SP, Relator: Min. SYDNEY SANCHES, Data de Julgamento: 23/06/1994,
} Tribunal Pleno, Data de Publicação: DJ 10-08-2001 PP-00003 EMENT VOL-02038-02 PP-00186. 
Em que pese o reconhecimento não impedir tal prática, a sobredita jurisprudência tem por efeito legitimar a vedação jurídica à tortura.

O exemplo da vedação da tortura ilustra a função da dignidade da pessoa humana como cláusula ética e jurídica de barreira, que fundamenta uma espécie de "sinal de pare", a estabelecer um "território proibido", onde o Estado não pode intervir e onde, além disso, lhe incumbe assegurar a proteção da pessoa, bem sua dignidade contra terceiros.

Ademais, opera o referido preceito como um "tabu", uma vez que a sua validade absoluta está condicionada a qualquer justificativa de matriz dogmática, não estando sujeita a ponderação, bem como não necessitando de ter sua eficácia jurídica regulada e nem reconhecida, já que está dentro de uma das ideias de direito natural.

Por fim, é válido destacar que, em tempos de recrudescimento da criminalidade e da prática da violência pública e privada, há que se estar atento para bloquear discursos que busquem legitimar, inclusive mediante apelos plebiscitários, a liberação da tortura como método oficial, ou, pelo menos, tolerável, de investigação, repressão e, sobretudo, castigo. 


\section{CAPÍTULO 2 - O REGIME DISCIPLINAR DIFERENCIADO}

\subsection{Breve Histórico da Lei de Execuções Penais}

O modelo penitenciário em vigor no Brasil, como é cediço, teve muitos de seus contornos traçados a partir do conjunto de transformações sofridas pela sociedade brasileira ao longo do período de exceção democrática, instaurado pela ditadura militar de 1964. Até este momento, só havia disciplinada a Lei no 3.274 de 1957, a qual compilava normas gerais acerca do regime penitenciário.

Findo o ano de 1964, o sistema penitenciário brasileiro retomou com veemência a sua utilidade, com o intuito de reforçar a repressão política e os ideários do regime então vigente. Notadamente, esta época foi estigmatizada por um defensivismo social excessivo e por um combate à periculosidade do indivíduo.

Mais adianta, em 1968, foi promulgado o Decreto $\mathrm{n}^{\mathrm{o}} 1.162$, o qual deu efeitos mais incisivos ao amplo arbítrio administrativo, bem como recaiu, naturalmente, sobre o regime disciplinar imposto. Nessa época, era aplicado o isolamento preventivo do faltoso, até a aplicação definitiva da reprimenda.

Por conseguinte, uma vez praticada a suposta falta disciplinar, deveria o interno ser conduzido à inspetoria da unidade, na qual caberia ao inspetor decidir por sua segregação preventiva ou não, tendo em conta a gravidade do fato. Todavia, no que se referia à gravidade do fato delituoso, o juízo era absolutamente livre para aplicar a sanção penal, ficando à míngua de dados objetivos fornecidos pela lei.

Além disso, o decreto previa as sanções de repreensão e de isolamento, dentro da própria cela, em alojamento, em cela de segurança, ou, ainda, em cela de segurança especial. Completava-se, então, o elenco de medidas repressivas e sanções secundárias de perda de favores, suspensão de visitas, rebaixamento de classificação disciplinar e apreensão de valores ou objetos. 
Nessa mesma linha de raciocínio do anteprojeto de Roberto Lyra, o regulamento da Guanabara, à época, impôs a reclusão, pelo máximo de 90 (noventa) dias em cela de segurança, que tinha as mesmas dimensões, higiene, aeração, e iluminação da cela comum, porém abastada de instalações sanitárias, cama e colchão.

Até então, não haveria nenhuma novidade, não fosse $o$ requinte do legislador no sentido de agravar, ainda mais, um confinamento já qualificado. Assim sendo, quando o gravame segregacionista parecia já ter alcançado o seu ápice com a cela de segurança, surgia a terceira espécie de isolamento: a cela de segurança especial, de evidente cunho retributivo, a qual tinha guarnição compatível com a periculosidade revelada pelo interno.

Feitas essas sintéticas considerações iniciais acerca da historiografia do sistema penitenciário brasileiro, mister ventilar algumas noções acerca da origem e base legal do Regime Disciplinar Diferenciado que, como aludido acima, tem seu embrião na Ditadura Militar.

De início, o Regime Disciplinar Diferenciado veio regulado em nível estadual, disciplinado pela primeira vez no estado de São Paulo, pela Resolução da Secretária de Administração Penitenciária n ${ }^{\circ}$ 26, de 04 de maio de 2001, na qual estipulou as medidas administrativas a serem tomadas perante a ocorrência de rebeliões ou qualquer tipo de manifestação violenta dentro das carceragens.

Posteriormente, foi editada a Medida Provisória $\mathrm{n}^{\circ} 28$, de 04 de fevereiro de 2002, segundo a qual estabelecia em seu art. $2^{\circ}$, a aplicação do Regime Disciplinar Diferenciado exclusivamente como sanção disciplinar destinada à presos ou condenados por crimes dolosos. Contudo, a medida provisória foi rejeitada pelo Congresso Nacional.

Em dezembro de 2003, foi publicada a Lei $\mathrm{n}^{\mathrm{o}}$ 10.792, que veio modificar a redação da Lei no 7.210/84, Lei de Execuções Penais (“LEP”), 
oficializando-se, com isso, o regime disciplinar diferenciado no ordenamento jurídico brasileiro.

A medida acabou por gerar inúmeros debates, seja no meio acadêmico, seja no meio social, vez que se revelou um tanto quanto rigorosa e, talvez, além dos limites de suportabilidade da pessoa humana, mais precisamente, se tornou causa de tortura psicológica.

Ao estabelecer o regime disciplinar diferenciado na "LEP", ampliou-se o espectro do novel à esfera nacional, ou seja, a rígida medida disciplinar que já vinha sendo adotada pelas Secretarias de Administração Penitenciária dos estados de Rio de Janeiro e São Paulo, passou a ser aplicada em âmbito federal. Por assim ser, o Regime Disciplinar Diferenciado, nas palavras do professor Salo de Carvalho, consiste no "regime integralmente fechado plus".

O RDD é considerado um regime fechadíssimo e vem com o objetivo de "tranquilizar" a sociedade, acenando ou iludindo à população brasileira, com a teórica eficiência dos Poderes Legislativo e Judiciário, elevando brados aos seus "poderes" de isolar um ser humano durante trezentos e sessenta dias por ele representar uma "grave ameaça" à sociedade.

Nesse sentido, Rodrigo Duque Estrada Roig preleciona que:

A partir de sua modificação pela Lei n. 10.792/2003, a Lei de Execução Penal passou a admitir a inclusão de presos no Regime Disciplinar Diferenciado (RDD), gestado dois anos antes em São Paulo, por meio da resolução SAP n. 26/2001, com a "promessa" de ser grande instrumento de enfrentamento da criminalidade organizada. ${ }^{9}$

Ademais, a luz da mesma ideia do i. doutrinador mencionado acima, expõe René Ariel Dotti que:

\footnotetext{
${ }^{8}$ CARVAlHO, Salo e WUNDERLICH, Alexandre. O Suplício de Tântalo: a Lei 10.792/03 e a Consolidação da Política Criminal do Terror. Disponível em <https://www.ibccrim.org.br/boletim_artigos/163-134-Janeiro-2004>. Acesso em 5 out. 2017.

${ }^{9}$ ROIG, Rodrigo Duque Estrada. Execução Penal Teoria Crítica. $3^{\text {a }}$ ed. Rio de Janeiro: Saraiva, 2017, p. 254.
} 
(...) A tendência do Congresso Nacional em editar uma legislação de pânico para enfrentar o surto da violência e a criminalidade organizada caracterizada pelo arbitrário aumento de pena de prisão e o isolamento diuturno de alguns condenados perigos durante dois anos - além de outras propostas fundadas na artimética do cárcere revela a ilusão de combater a gravidade do delito com a exasperação das penas. ${ }^{10}$

A contemporaneidade do regime diferenciado oculta a assunção dos mesmos paradigmas imperantes no direito penal brasileiro desde os séculos XIX, tempo este em que se começou a avultar a privação de liberdade como resposta penal.

Percebe-se que os discursos seculares se repetem e se reeditam diuturnamente, sobretudo quando se trata da seara criminal, em que a primeira medida a ser sancionada é - quase sempre - a legitimação da segregação absoluta e do retribucionismo. Em que pese terem roupagens próprias de cada conjuntura histórica, tais medidas são a todo tempo reinseridas em uma mesma programação criminalizante.

Há críticas ferozes no que tange à existência obsoleta desse modelo de regime no atual Estado Democrático de Direito. Isso porque, a mencionada forma de Estado deve libertar-se dos discursos alarmistas e periculosistas, típicos de regimes de exceção.

Por assim ser, seria insustentável e não mais subsistiria o isolamento absoluto de um indivíduo, ante os já mencionados princípios constitucionais da dignidade da pessoa humana, da igualdade, da secularização e da presunção de inocência.

O que se vê, contudo, é uma realidade contrastante entre os limites legais e os princípios constitucionais, não apenas quanto às rigorosas condições impostas ao sujeito segregado, mas também em razão do longo período de sofrimento vivenciado, caracterizando a tortura. Dito isto, ainda que haja a

\footnotetext{
${ }^{10}$ DOTTI, René Ariel. Movimento Antiterror e a Missão da Magistratura. $2^{\mathrm{a}}$ ed. Curitiba: Juruá, 2005,
} p.34. 
legalidade formal da lei $\mathrm{n}^{\circ} 10.792$, de 2003 , deve-se atentar para a legalidade substancial desta norma.

O modelo penitenciário em vigor no Brasil, como é cediço, teve muitos de seus contornos traçados a partir do conjunto de transformações sofridas pela sociedade brasileira ao longo do período de exceção democrática, instaurado pela ditadura militar de $1964 .{ }^{11}$

Até este momento, só havia disciplinada a Lei no 3.274 de 1957, segundo a qual compilava normas gerais acerca do regime penitenciário. Tais normas, nas palavras do ilustríssimo Defensor Público, Rodrigo Duque Estrada Roig eram "de cunho eminentemente programático e organizacional, sem significativos reflexos na realidade carcerária". ${ }^{12}$

\subsection{Regime Disciplinar Diferenciado}

O Regime Disciplinar Diferenciado (“RDD”) possui natureza de sanção disciplinar, caracterizando-se pela duração máxima de 360 dias, sem que haja prejuízo de sua repetição pela reiteração da prática, até o limite de $1 / 6$ da pena aplicada.

No que tange à duração do "RDD", o colendo Superior Tribunal de Justiça já se manifestou no sentido de ser desproporcional a imposição do referido castigo no prazo máximo de duração, ou seja, de 360 dias, sem que tenha havido a individualização da sanção de forma adequada, bem como motivada.

À exemplo disso, colaciona-se o precedente no Habeas Corpus $\mathrm{n}^{\circ}$ 89935/BA da $6^{a}$ Turma do c. Superior Tribunal de Justiça:

EXECUÇÃO PENAL. HABEAS CORPUS. 1. REGIME DISCIPLINAR DIFERENCIADO (RDD). INOCORRÊNCIA DE QUALQUER DAS HIPÓTESES LEGAIS. IMPOSIÇÃO.

\footnotetext{
11 Ibid. p. 125.

12 Ibid. p. 125.
} 
IMPOSSIBILIDADE. 2. DECISÃO DO JUIZ DAS EXECUÇÕES EM PROCESSO JUDICIAL. NECESSIDADE. 3. FALTA DE MANIFESTAÇÃO DA DEFESA. ILEGALIDADE. OCORRÊNCIA. 4. LIMITE TEMPORAL MÁXIMO DE 1 ANO. IMPOSIÇÃO SEM MOTIVAÇÃO. IMPOSSIBILIDADE. INDIVIDUALIZAÇÃO DA SANÇÃO. NECESSIDADE. PRINCÍPIO DA PROPORCIONALIDADE. 5. ORDEM CONCEDIDA. 1. Incabível a inclusão de preso em RDD se inocorrente no caso qualquer das hipóteses legais, previstas no artigo 52 da Lei de Execucoes Penais. 2. O Regime Disciplinar Diferenciado é sanção disciplinar que depende de decisão fundamentada do juiz das execuções criminais e determinada no curso do processo de execução penal. 3. A decisão judicial sobre a inclusão do preso em regime disciplinar será precedida de manifestação do Ministério Público e da defesa, o que não foi propiciado no presente caso. 4. Desproporcional a imposição do regime disciplinar diferenciado no seu prazo máximo de duração, de um ano, sem uma individualização da sanção adequadamente motivada (Inteligência do artigo 57 da Lei de Execução Penal). 5. Ordem concedida para determinar a transferência do paciente do regime disciplinar diferenciado, retornando para o Conjunto Penal de Feira de Santana, onde se encontrava. Efeitos estendidos aos demais presos na mesma situação. ${ }^{13}$

O "RDD" recolhe o apenado em cela individual, pela limitação de visitas semanais a duas pessoas, sem contar as crianças, com duração de 2 horas e pelo direito de saída da cela por 2 horas diárias para banho de sol, conforme disposto no art. 52 da "LEP".

Além disso, os destinatários do "RDD" podem ser presos provisórios e apenados, desde que tenha se verificado a prática de fato previsto como crime doloso, quando da ocorrência de "subversão da ordem ou disciplina interna" (art. 52), ou para aqueles que apresentem alto risco a ordem e a segurança do estabelecimento penal ou da sociedade (art. 52, $\$ 1^{\circ}$ ) e os condenados sobre os quais recaiam fundadas suspeitas de envolvimento ou participação, a qualquer título, em organizações criminosas, quadrilha ou bando (art. 52, $2^{\circ}$ ).

Há o entendimento segundo o qual existem duas modalidades de "RDD", sendo a primeira delas o "RDD" punitivo, o qual decorre da prática de

\footnotetext{
${ }^{13}$ STJ - HC: 89935 BA 2007/0208711-7, Relator: Ministra MARIA THEREZA DE ASSIS MOURA, Data de Julgamento: 06/05/2008, T6 - SEXTA TURMA, Data de Publicação: DJe 26/05/2008.
} 
fato previsto como crime doloso ou de fato que ocasione subversão da ordem ou disciplina internas dos presídios (art. 52, caput).

Conforme disposto no já mencionado art. 52, o "RDD" tem como exigência a instauração de procedimento administrativo para apuração dos fatos (art. 59), requerimento circunstanciado da autoridade competente (art. 54, $\S 1^{\circ}$ ), manifestação do ministério público e da defesa (art. 54, §2ºm ), bem como despacho fundamentado do juiz competente (art. 54, caput).

Quanto à segunda modalidade de "RDD" existe a cautelar, a qual é aplicável aos presos com evidente suspeita de envolvimento ou participação em organizações criminosas, quadrilhas ou bando (art. 52, $\S 2^{\circ}$ ).

Essa modalidade está adstrita ao poder geral de cautela do magistrado, além de não ser necessária a prévia manifestação do Ministério Público e da defesa, pelo entendimento de ser esta uma situação de perigo e urgência.

Mister fazer uma análise acerca da prescindibilidade da manifestação do parquet e da defesa. É inconstitucional a determinação do preso no regime de "RDD" cautelar, uma vez que viola os princípios da legalidade, da presunção de inocência e da ampla defesa.

Mesmo que em realidade adversa da comum, por se tratar de situação atípica, deveria este castigo atender às imposições legais do art. 54, $1^{\circ}$ e art. 60 da "LEP" os quais dispõem ser obrigatório o requerimento circunstanciado da autoridade competente, bem como há a necessidade de despacho fundamentado do juízo competente.

A luz dessa crítica, preleciona o i. doutrinador Rodrigo Duque Estrada Roig que:

Salvo melhor juízo, se não corretamente entendido como inconstitucional, e anticonvencional (por violação da legalidade e presunção de inocência), a imposição do RDD cautelar deveria sim atender às exigências de manifestação do Ministério Público e da defesa, além, naturalmente, da necessidade de requerimento 
circunstanciado da autoridade competente (art. 54, $\$ 1^{\circ}$ ) e do despacho fundamentado do juiz competente (art. 60). ${ }^{14}$

Cumpre ainda analisar algumas questões acerca do tema em análise. No caso do "RDD" estadual, deve-se aplicar analogicamente o art. 57 do Decreto $n^{\circ} 6.049 / 2007$, o qual dispõe que:

O cumprimento do regime disciplinar diferenciado exaure a sanção e nunca poderá ser invocado para fundamentar novo pedido de inclusão ou desprestigiar o mérito do sentenciado, salvo, neste último caso, quando motivado pela má conduta denotada no curso do regime e sua persistência no sistema comum. ${ }^{15}$

Isto quer dizer que, os fundamentos do primeiro pedido para inclusão do preso em "RDD" não podem ser os mesmos do novo pedido. Ademais, o fato de o preso ter cumprido essa sanção disciplinar anteriormente não pode ser motivo para novo pedido de reinserção no "RDD".

É válido também mencionar que o cumprimento do "RDD" jamais poderá ser utilizado contra o encarcerado, como forma de desprestigiá-lo em sua sentença meritória, isto é, o cumprimento do castigo não pode ser utilizado contra o indivíduo, mesmo que disciplinarmente.

No que tange à constitucionalidade do referido regime, o STJ tem o entendimento segundo o qual é constitucional o "RDD", a luz dos julgamentos nos precedentes dos Habeas Corpus $\mathrm{n}^{\circ}$ 44049/SP e Habeas Corpus $\mathrm{n}^{\circ}$ 40300/RJ, in verbis:

HABEAS CORPUS. DIREITO PENAL. ARTIGO 52 DA LEI DE EXECUÇÃO

PENAL.REGIMEDISCIPLINARDIFERENCIADO.INCONSTITU CIONALIDADE. INOCORRÊNCIA. TEMPO DE DURAÇÃO. LEGALIDADE. ORDEM DENEGADA. 1. É constitucional o artigo 52 da Lei $n^{\circ} 7.210 / 84$, com a redação determinada pela Lei $n^{\circ}$ 10.792/2003. 2. O regime diferenciado, afora a hipótese da falta grave que ocasiona subversão da ordem ou da disciplina internas,

\footnotetext{
${ }^{14}$ ROIG, Rodrigo Duque Estrada. Op. cit., p. 256.

15 Disponível em: 〈http://www.planalto.gov.br/ccivil_03/_ato2007-2010/2007/decreto/d6049.htm〉. Acesso em 29 set. 2017.
} 
também se aplica aos presos provisórios e condenados, nacionais ou estrangeiros, "que apresentem alto risco para a ordem e a segurança do estabelecimento penal ou da sociedade". 3. A limitação de 360 dias, cuidada no inciso I do artigo 52 da Lei $n^{\circ} 7.210 / 84$, é, enquanto prazo do regime diferenciado, específica da falta grave, não se aplicando à resposta executória prevista no parágrafo primeiro do mesmo diploma legal, pois que há de perdurar pelo tempo da situação que a autoriza, não podendo, contudo, ultrapassar o limite de 1/6 da pena aplicada. 4. Em obséquio das exigências garantistas do direito penal, o reexame da necessidade do regime diferenciado deve ser periódico, a ser realizado em prazo não superior a 360 dias. 5 . Ordem denegada. ${ }^{16}$

HABEAS CORPUS. REGIME DISCIPLINAR DIFERENCIADO. ART. 52 DA LEP. CONSTITUCIONALIDADE. APLICAÇÃO DO PRINCÍPIO DA PROPORCIONALIDADE. NULIDADE DO PROCEDIMENTO ESPECIAL. REEXAME DE PROVAS. IMPROPRIEDADE DO WRIT. NULIDADE DA SENTENÇA CONDENATÓRIA NÃO RECONHECIDA. 1. Considerando-se que os princípios fundamentais consagrados na Carta Magna não são ilimitados (princípio da relatividade ou convivência das liberdades públicas), vislumbra-se que o legislador, ao instituir o Regime Disciplinar Diferenciado, atendeu ao princípio da proporcionalidade. 2. Legitima a atuação estatal, tendo em vista que a Lei n. ${ }^{\circ}$ 10.792/2003, que alterou a redação do art. 52 da LEP, busca dar efetividade à crescente necessidade de segurança nos estabelecimentos penais, bem como resguardar a ordem pública, que vem sendo ameaçada por criminosos que, mesmo encarcerados, continuam comandando ou integrando facções criminosas que atuam no interior do sistema prisional liderando rebeliões que não raro culminam com fugas e mortes de reféns, agentes penitenciários e/ou outros detentos e, também, no meio social. 3. Aferir a nulidade do procedimento especial, em razão dos vícios apontados, demandaria o revolvimento do conjunto fático-probatório apurado, o que, como cediço, é inviável na estreita via do habeas corpus. Precedentes. 4. A sentença monocrática encontra-se devidamente fundamentada, visto que o magistrado, ainda que sucintamente, apreciou todas as teses da defesa, bem como motivou adequadamente, pelo exame percuciente das provas produzidas no procedimento disciplinar, a inclusão do paciente no Regime Disciplinar Diferenciado, atendendo, assim, ao comando do art. 54 da Lei de Execução Penal. 5. Ordem denegada. ${ }^{17}$

${ }^{16}$ STJ - HC: 44049 SP 2005/0077809-8, Relator: Ministro HÉLIO QUAGLIA BARBOSA, Data de Julgamento: 12/06/2006, T6 - SEXTA TURMA, Data de Publicação: DJ 19/12/2007 p. 1232.

${ }^{17}$ STJ - HC: 40300 RJ 2004/0176564-4, Relator: Ministro ARNALDO ESTEVES LIMA, Data de Julgamento: 07/06/2005, T5 - QUINTA TURMA, Data de Publicação: DJ 22/08/2005 p. 312 RT vol. 843 p. 549. 
Em que pese esta ser a posição majoritária, é necessário tecer algumas considerações acerca do "RDD".

A estrutura do "RDD" vigente advém de uma nova visão das autoridades no que tange à importância do domínio do espaço penitenciário, haja vista que as carceragens são construções sociais complexas e carregam a conjunção de dois tipos de ambiente: espaço real (físico) e espaço ideal (abstrato mental), o que faz com que ele seja, ao mesmo tempo, material, funcional e ideológico.

Tal dominação torna possível controlar e monitorar comunicações dos detentos, permite a constância da inspeção, bem como torna o meio eficaz para a ubiquidade dos agentes penitenciários nesse meio espacial.

Rodrigo Duque Estrada Roig citando Alvino Augusto de Sá vai dizer que:

O preso estabelece e desenvolve com a edificação carcerária uma relação simbiótica. Uma relação de reavivamento, de seleção, de reforçamento de experiências. Uma relação simbiótica que, conforme passam os anos de prisão, sua incompatível rotina diária certamente vai se sedimentando cada vez mais. Ela será tanto mais intensa e criará sulcos tanto mais profundo, quanto maior for o isolamento, e quanto maior for a pena. (...). Portanto, é provável que tal relação do preso com a edificação carcerária venha a lhe criar marcas em seu psiquismo, tanto mais ressonantes quanto mais exclusiva e duradoura tiver sido a supracitada relação. ${ }^{18}$

Nessa toada, o preso por meio de sua ligação exacerbada com o espaço celular e desumano, reduz pouco a pouco a sua própria noção acerca dos atos vitais mais banais, como respirar, movimentar-se e viver. Por assim ser, quanto maior é a duração de sua pena, menor será a sensação de ainda estar vivo, no sentido de sentir alívio e prazer.

Conforme já mencionado no subtópico anterior desse mesmo capítulo, a aplicação do isolamento integral como modelo de castigo sempre esteve

\footnotetext{
${ }^{18}$ ROIG, Rodrigo Duque Estrada. apud DE SÁ, 1990, Op. cit., p. 250.
} 
presente no sistema processual penal brasileiro, o qual veio a atingir sua plenitude a partir do Código Penal de 1890.

Contudo, a ideologia segregacionista de presos tidos como especiais passou a ser propagada com a elaboração dos projetos de códigos penitenciários para o Brasil, os quais preconizaram a criação da denominada “cela de segurança" e tiveram o seu ápice de aplicação durante a Ditadura Militar.

Nesse sentido:

No Brasil, o emprego de isolamento absoluto como forma de castigo esteve presente desde os primeiros regulamentos penitenciários do século XIX, atingindo seu ápice com o Código Penal de $1890 .{ }^{19}$

As considerações feitas ao "RDD" indicam a incoerência desse regime com o contemporâneo Estado Democrático de Direito, o qual deve rechaçar discursos alarmistas e periculosistas, específicos da época em que o meio de prova no processo penal eram as ordálias. Sob essa ótica, não haveria mais como existir o isolamento absoluto, ante aos princípios constitucionais da dignidade da pessoa humana, igualdade e presunção de inocência.

A propósito:

As críticas ao Regime Disciplinar Diferenciado apontam para a sua insustentabilidade no atual Estado Democrático de Direito, que deve libertar-se dos discursos alarmistas e periculosistas, típicos de regimes de exceção. Nessa perspectiva, não mais subsistiria o isolamento absoluto ante os princípios constitucionais da dignidade da pessoa humana, igualdade, secularização e presunção de inocência. ${ }^{20}$

Como já mencionado no primeiro capítulo desta monografia, todos os direitos fundamentais constitucionais têm como parâmetro de aplicação o princípio fundamental da dignidade da pessoa humana e é pelo processo, não

\footnotetext{
${ }^{19}$ Ibid. p. 261.

${ }^{20}$ Ibid. p. 262.
} 
só de conhecimento, mas também de execução, que há a garantia de proteção do status libertatis do cidadão. À face disso, o resguardo da dignidade da pessoa humana deve ser o suporte da aplicação da execução da pena.

Todavia, o que ocorre na prática é o oposto entre os limites legais previstos em normas infraconstitucionais e os princípios constitucionais, os quais diuturnamente são violados, não apenas quanto às rigorosas condições impostas aos apenados nos presídios brasileiros, mas, sobretudo, em razão do longo período de sofrimento vivenciado.

Conforme afirma Rodrigo Roig, a própria Anistia Internacional veda esse tipo de tortura, in verbis:

\footnotetext{
Vale lembrar que as novas regras mínimas das nações unidas para tratamento de presos vedam o confinamento solitário prolongado que consiste no confinamento por 22 horas ou mais, por dia, sem contato humano significativo, aplicado por mais de 15 dias consecutivos (regra 43.1 "b" c/c 44) e que a própria corte interamericana de direitos humanos já se manifestou no sentido de que o isolamento prolongado e a privação da comunicação correspondem a tratamento cruel e desumano. ${ }^{21}$
}

No que se refere ao desrespeito ao princípio da igualdade, esse está consubstanciado no tratamento discriminatório, sem que haja a sua justificativa, uma vez que o detento pode ser considerado um indivíduo perigoso ou para a sociedade ou para o sistema prisional, o que demonstra haver, na verdade, a perseguição não no sentido de fiscalizar ou reprimir, mas de distinguir os sujeitos daquela unidade prisional.

Com isso, o poder disciplinar tem o condão de transformar esse preso específico no foco da intervenção, identificando-o por intermédio de uma qualidade distintiva das dos demais, o que dá supedâneo para a construção da individualidade do detento não como sujeito de direito, mas como um inimigo da sociedade.

${ }^{21}$ Ibid. p. 262. 
Flagrante é, portanto, a ruptura dos parâmetros constitucionais da dignidade da pessoa humana com o devido processo de execução, evidenciando-se assim o aspecto totalitário do "RDD". Nesse sentido, Luigi Ferrajoli leciona que:

Disciplina diretamente das pessoas, antes que a de seus comportamentos, do seu ser, antes que de seu atuar, constitui um traço característico dos regimes totalitários, já que lesionam tanto a igualdade quanto a liberdade ${ }^{22}$.

Por último, não pode ser esquecido o princípio constitucional da presunção de inocência, o qual foi aniquilado pelo "RDD", pois esse sistema abarca não só os presos provisórios, mas como também inclui indivíduos sobre os quais haja a mera suspeita de associação criminosa, "sem o necessário juízo de certeza para a inflação de todas as consequências deletérias dele advindas". ${ }^{23}$

\subsection{A Obscuridade na Previsão Legal do Artigo 52 da Lei de Execuções Penais}

Antes de iniciar a dissertar sobre o referido tema, é imperioso destacar ilustre colocação de Cesare Beccaria, ainda pelos idos de 1764:

Se a interpretação arbitrária das leis é um mal, também o é a sua obscuridade, pois precisam ser interpretadas. Esse inconveniente é maior ainda quando as leis são escritas em língua vulgar. ${ }^{24}$

Segundo o artigo 52 da Lei de Execuções Penais (“LEP”), comete falta grave o condenado à pena privativa de liberdade quem incitar ou participar de movimento para subverter a ordem ou a disciplina, fugir, possuir, indevidamente, instrumento capaz de ofender a integridade física de outrem,

\footnotetext{
${ }^{22}$ FERRAJOLI, Luigi. Derechos y garantías. La ley de más débil. Madrid: Trotta, 1999, p. 403.

${ }^{23}$ ROIG, Rodrigo. Op. Cit. p. 263.

${ }^{24}$ BECCARIA, Cesare. Dos Delitos e das Penas. $2^{\text {a }}$ ed. São Paulo, Edipro de Bolso: 2016, p. 28.
} 
provocar acidente de trabalho, descumprir, no regime aberto, as condições impostas, inobservar o dever de obediência ao servidor e respeito a qualquer pessoa com quem deva relacionar-se e o dever de execução do trabalho, das tarefas e das ordens recebidas e, por fim, praticar fato previsto como doloso. ${ }^{25}$

É válido destacar que o artigo 52, disciplina como prática de falta grave o condenado segundo o qual incita ou participa de movimento para subverter a ordem ou a disciplina, trata-se de evidente exemplo de indeterminação conceitual jurídica, não resolvida pela própria inconsistência na definição de disciplina, trazida pela "LEP” em seu artigo 44, a ver:

Art. 44. A disciplina consiste na colaboração com a ordem, na obediência às determinações das autoridades e seus agentes e no desempenho do trabalho. Parágrafo único. Estão sujeitos à disciplina o condenado à pena privativa de liberdade ou restritiva de direitos e o preso provisório. ${ }^{26}$

De modo análogo, a noção de ordem carece de cunho objetivo, haja vista que é pautada por parâmetros casuísticos e sempre se encontra em conformidade com interesses maiores da Administração. Nesse sentido, Michel Foucault vai lecionar que "o discurso da disciplina é alheio ao da lei e da regra enquanto efeito da vontade soberana". ${ }^{27}$

No que tange à indeterminação conceitual jurídica, cumpre transcrever as lições de Nilo Batista:

A função da garantia individual exercida pelo princípio da legalidade estaria seriamente comprometida se as normas que definem os crimes não dispusessem de clareza denotativa na significação de seus elementos, inteligível por todos os cidadãos. Formular tais tipos penais "genéricos e vazios", valendo-se de "cláusulas gerais" ou "conceitos indeterminados" "ou ambíguos",

\footnotetext{
${ }^{25}$ Disponível em: <http://www.planalto.gov.br/ccivil_03/leis/L7210.htm〉. Acesso 2 out. 2017.

${ }^{26}$ Disponível em: <http://www.planalto.gov.br/ccivil_03/leis/L7210.htm> Acesso 2 out. 2017.

27 FOUCAULT, Michel. Microfísica do Poder. Disponível em: 〈http://petletras.paginas.ufsc.br/files/2017/03/foucault-microfisica-do-poder.pdf $\rangle$. Acesso 5 out. 2017.
} 
equivale teoricamente a nada formular, mas é prática e politicamente muito nefasto e perigoso. ${ }^{28}$

A amplitude semântica do artigo 52 da LEP é indubitavelmente um fator de desestabilização das garantias dos reclusos, uma vez que as decisões disciplinares se apresentam de forma ambígua e lacunar, ampliando-se, dessa forma, o arbítrio do corpo administrativo.

Frisa-se, outrossim, que a punição do indivíduo nos termos deste dispositivo depende de completo alvedrio da autoridade penitenciária, a quem compete a interpretação acerca do que desestabiliza ou não a ordem e a disciplina carcerárias, gerando infindáveis incertezas.

Vale, ainda, ressaltar que o artigo em tela não exige que se pratique violência ou ameaça. Segundo Mirabete, a falta também se verifica:

(...) nos movimentos pacíficos de recusa ao trabalho, de volta às celas, de greve de fome, de algazarra etc. não importa, também, o fim visado pelo movimento, que pode até ser considerado "justo", como é o de pretender melhores condições de trabalho, oportunidades de recreação etc., tais reinvindicações devem ser efetuadas na forma dos regulamentos. ${ }^{29}$

Urge, portanto, tecer algumas conclusões de ordem prática: não há qualquer distinção quanto à maior ou menor gravidade das condutas praticadas, sendo aposto um rol único de faltas, além de só se levar em consideração a personalidade do interno, razão pela qual o eixo punitivo acaba sendo deslocado do fato praticado, para a pessoa do faltoso, consagrando um direito executivo-penal de autor.

Sem embargo da imprecisão terminológica entre o que poderia vir a ser perturbação da ordem ou disciplina, há também a subversão do princípio da legalidade cometida pela Lei $n^{\circ} 10.792$, de 2003, uma vez que ao deixar de

\footnotetext{
${ }^{28}$ BATISTA, Nilo. Introdução Crítica ao Direito Penal brasileiro. $5^{\mathrm{a}}$ ed. Rio de Janeiro: Renavam, 2001, p. 78.

${ }^{29}$ MIRABETE, Julio Fabbrini. Execução Penal. $9^{a}$ ed. São Paulo: Atlas, 2000, p. 138.
} 
identificar quais condutas seriam passíveis de recolhimento em cela de segurança especial, a norma reforçou o arbítrio desregrado da autoridade, consagrando um quadro de grave insegurança jurídica, típico de instituições de estados totalitários.

Em lugar de um julgamento disciplinar fundado na objetividade jurídica da falta, realiza-se uma autêntica anamnese da periculosidade do autor frente à incolumidade estrutural da prisão, em que a falta é tida como um desvio antagônico aos fins colimados pela execução e o preso é tratado como um foco infeccioso no interior do "sadio" organismo do cárcere.

Isso faz com que haja a elevação de segurança e disciplina a fins de alta precedência e reclama um controle ilimitado sobre o preso, do que resulta o completo sacrifício de sua autonomia. Não se lhe permite fazer escolhas: as opções são regradas minuciosamente e as que dependerem de uma decisão humana, devem provir dos funcionários de modo injustificado e sem explicações, o que acarreta na exigência de uma obediência cega simplesmente.

Não obstante, há ainda mais motivações para o fomento da tensão entre o poder público e a massa carcerária. Isso porque, tal conjuntura acaba por perpetuar três fatores.

O primeiro deles são os procedimentos de apuração de faltas e imposição de sanções no interior das unidades prisionais, os quais são inerentemente inquisitoriais. O segundo está na normatização das faltas disciplinares, pois a lei é extremamente lacunar e dúbia, viola-se, portanto, o princípio da legalidade. Por último há as sanções disciplinares que, em muitos casos, possuem efeitos semelhantes aos da aplicação da própria pena.

Neste diapasão, afirma Salo de Carvalho:

No interior do modelo antigarantista toda e qualquer conduta perversa é tida como ilícita, visto que as zonas de valoração moral e jurídica são simétricas. Logo, se a sanção no modelo garantista é uma resposta jurídica à violação da norma (quia prohibitum), no 
modelo inquisitivo traveste-se em reposta quia peccatum, punindose o infrator não pelo resultado danoso produzido, mas por quão perigoso ou perverso é. ${ }^{30}$

Apropriado, então, afirmar que a categoria periculosidade rompe com qualquer possibilidade de construção de um modelo processual de garantias, visto ser o extremo oposto do princípio da presunção de inocência.

Destaque-se que, a prova cabal da falência deste modelo de tratamento reside na dura realidade e reincidência da maioria dos apenados anteriormente contemplados com o benefício de Livramento Condicional.

Nesse sentido:

As nefastas consequências do encarceramento revelam o fracasso do Direito penal, que ao invés de provocar, na fase de execução, a reintegração do condenado, promove a elevação dos índices de reincidência ${ }^{31}$

De todo modo, pode-se concluir que a execução da pena no Brasil, especialmente no concernente a sua vertente disciplinar, padece de excessiva subjetivação, tendente a transpor as fronteiras da legalidade e sublimar a pessoa do apenado, desconsiderando a concretude do fato e a própria natureza externa da ação faltosa.

\footnotetext{
${ }^{30}$ CARVALHO, Salo de. Crítica à Execução Penal: Doutrina, Jurisprudência e Projetos Legislativos. $2^{\mathrm{a}}$ ed. Rio de Janeiro: Lumen Juris, 2007, p. 3/28.

${ }^{31}$ JÚNIOR, Miguel Reale. Novos Resumos do Sistema Criminal. $1^{\text {a }}$ ed. Rio de Janeiro: Forense, 1983, p. 27.
} 


\section{CAPÍTULO 3 - O REGIME DISCIPLINAR DIFERENCIADO COMO EFEITO DO DIREITO PENAL DO INIMIGO}

O Regime Disciplinar Diferenciado tem intima ligação com a doutrina do Direito Penal do Inimigo, uma vez que todas as proposições do já mencionado artigo 52 da Lei de Execuções Penais, demonstram restrições dirigidas não ao fato delituoso, mas a determinada classe de autores. Há a pretensão, portanto, de trazer vicissitudes para a vida dos condenados no interior do cárcere, não por terem cometido algum delito, mas devido ao julgamento dos responsáveis pelo controle administrativo das penitenciárias.

Tal julgamento é de ordem subjetiva e é destinado àqueles que representam risco para a sociedade ou administração dos presídios, bem como os suspeitos de participarem de bandos ou organizações criminosas.

Verifica-se que esta iniciativa conduz a um temerário direito penal do autor, no qual não importa o que se faz ou omite (fato) e sim o sujeito, a personalidade, as características daquele que veio a delinquir (pessoa do autor).

Além do mais, é indubitável que há a existência de um estado de terror permanente dentro do Brasil. Contudo, a resposta para este perverso cotidiano vem por meio de uma política criminal equivocada, a qual reproduz e multiplica a própria violência, demonstrando verdadeiro estado de exceção, por meio do recrudescimento dos castigos penitenciários.

É válido destacar que, ao prever na "LEP" o "RDD”, expande-se não só o âmbito de atuação da ultima ratio de qualquer ordenamento jurídico, mas, na verdade, rompe-se com toda a estrutura do Estado Democrático de Direito e o princípio da igualdade, uma vez que há a imposição de uma reação penal diferenciada segundo o perfil do autor e não do fato realizado.

A referida política demonstra de forma clara a tendência de se adotar um direito penal do inimigo, segundo o qual desconsidera determinada classe 
de cidadãos, a partir de uma classificação que se impõe por mero juízo subjetivo, que impõe a distinção entre cidadãos e "inimigos" da sociedade.

Posto isto, convém destacar obra do Doutrinador Günther Jakobs, o qual reconhece ser legítima a "guerra contra o terror", que acabou sendo deflagrada após os atentados de 11 de setembro de 2001.

Diante dessa conjuntura, passou-se a transferir guerrilheiros talibãs e elementos ligados à Al-Qaeda para a base de Guantanamo em Cuba, onde esses indivíduos ficavam detidos em celas minúsculas, com direito de sair somente 15 minutos por dia. Foram, ainda, suprimidos os direitos fundamentais, como os de ser julgado e ter contra si uma acusação formal.

Em entrevista do ano de 2006 a imprensa argentina, o referido autor definiu o Direito Penal do Inimigo da seguinte forma:

É um fenômeno que se dá em todos os ordenamentos jurídicos dos países ocidentais e consiste em sancionar a conduta de um sujeito perigoso em uma etapa bem anterior ao ato delitiva, sem esperar uma lesão posterior. Se sanciona a conduta e a periculosidade do sujeito e não os seus atos. $\mathrm{O}$ mesmo fenômeno se dá no âmbito processual, especialmente com a restrição da liberdade de alguns. (...). Em essência, o conceito de direito penal do inimigo é uma noção descritiva que define algo existente nos ordenamentos democráticos atuais e designa aqueles suspeitos perigosos para distingui-los daqueles outros suspeitos que se produz uma relação jurídica entre cidadãos. ${ }^{32}$

Demonstra-se de forma clara que a punição do indivíduo se dá em razão da sua periculosidade e não pelos atos que por ventura ele tenha praticado, até porque, nas suas ideias, o ideal é que o sujeito seja punido antes mesmo de delinquir.

Nesse sentido, diz que há dois polos ou tendências no Direito Penal, quais sejam: o tratamento para com o cidadão, segundo o qual se espera a exteriorização da conduta, para que haja a reação do Estado em relação a essa

32 GÜNTHER, Jakobs. El Enemigo Tiene Menos Derechos. Disponível em $\langle$ http://www.lanacion.com.ar/826258-el-enemigo-tiene-menos-derechos-dice-gunther-jakobs $>$. Acesso em 2 out. 2017. 
ação ilícita ou o tratamento com o inimigo, que é interceptado previamente, visto que ele é combatido devido à sua periculosidade.

Dessa forma, ao distinguir os cidadãos dos inimigos do Estado, há a polarização do Direito Penal, dando ao primeiro indivíduo o direito de ser respeitado, ter todas as garantias penais e processuais asseguradas, tal qual o devido processo legal, ao passo que, com o inimigo da sociedade, não há que se falar em garantias e direitos assegurados, pelo contrário, contra ele há um verdadeiro "procedimento de guerra".

Ademais, o inimigo não pode ser considerado uma pessoa, razão pela qual a antecipação de sua punição torna-se legítima, assim como a desproporcionalidade das penas aplicadas, a relativização de certas garantias processuais e a criação de lei severas, pois "um indivíduo que não admite ser obrigado a entrar em um estado de cidadania não pode participar dos benefícios do conceito de pessoa". ${ }^{33}$

A despeito disso, faz-se necessário traçar as três principais características do Direito Penal do Inimigo, quais sejam: o adiantamento da do âmbito de incidência da punibilidade, o qual passa a ter enfoque prospectivo, punindo o fato criminoso futuro, ao invés da tradicional perspectiva retrospectiva, que criminaliza o fato já consumado.

O Direito Penal do Inimigo é, na verdade, o modelo de Direito Penal Parcial, com a qual se pune de modo antecipado e mais severo, restringindo-se, com isso, a liberdade mesmo antes do cometimento de qualquer delito.

Oportuno, ainda, salientar que o modelo de imputação proposto pelo chamado funcionalismo sistêmico, se inspira na ideia central de que a punibilidade do delito deriva da violação de um dever, ou seja, a realização do delito consiste no rompimento do comando normativo, gerando, portanto, a correspondente sanção.

\footnotetext{
${ }_{33}$ JAKOBS, Günther. MELIA, Manuel Cancio. Direito Penal do Inimigo. Noções e Críticas. $6^{\mathrm{a}}$ ed. Porto Alegre: Livraria do Advogado, 2012, p. 35.
} 
O objetivo central desse sistema é o de obter a estabilização da norma, por meio do reconhecimento social generalizado de necessidade de subsunção da norma ao fato delituoso, bem como a submissão dos cidadãos a ela.

Segundo essa perspectiva, a sociedade é formada tanto por sistemas quanto e subsistemas autopoiéticos, sendo o Direito Penal o subsistema do sistema jurídico, o qual têm uma concepção fechada e que pretende sua própria subsistência como sistema.

Nesse sentido, o propósito do Direito Penal é a busca da estabilização da norma. Com isso, a aplicação da pena ou da medida de segurança, tem por objetivo gerar a confiança da sociedade, por meio da demonstração de que a norma desafiada pelo autor do delito tem vigência, pois o pune.

$\mathrm{O}$ esquecimento da condição humana do autor do delito presente nesta proposição dogmática é o que permite a formulação de um "Direito Penal do Inimigo", o que acaba por abrir portas às construções legislativas de matizes menos garantistas.

Assim, fica evidente que a elaboração legislativa brasileira recente, em geral, e especialmente no caso da regulamentação do Regime Disciplinar Diferenciado, não só se vincula a uma Política Criminal equivocada, de ingresso em um ciclo vicioso de responder à violência com mais violência, como também se encontra respaldada por uma perigosa concepção dogmática defendida como aposta para a redução da violência para o futuro.

Por isso, a repulsa ao modelo dogmático funcionalista-sistêmico é uma exigência que, se não atende a convicção de alguns críticos da alavanche legislativa penal que vivemos, deve derivar, no mínimo, da coerência para com tal crítica.

Em suma, é necessário centrar a atenção no fato de que legislações de matizes como os da Lei $\mathrm{n}^{\circ}$ 10.792/03 correspondem por um lado a uma Política Criminal expansionista, simbólica e equivocada e por outro, a um esquema dogmático pouco preocupado com a preservação dos direitos e garantias 
fundamentais do homem. Por isso, há a necessidade de cuidar-se com relação aos perigos que vêm tanto de um quanto de outro. 


\section{CAPÍTULO 4 - CRÍTICAS À IDEIA DE UM DIREITO PENAL DO INIMIGO}

O poder punitivo do Estado sempre conferiu a alguns setores da coletividade um tratamento condizente não com o de ser-humano, mas de objeto. Para esta parcela de indivíduos, sempre lhe foram negadas as garantias do direito penal liberal, bem como dos direitos humanos, posto que tais sujeitos, a todo momento, são considerados seres daninhos ou inimigos da sociedade.

O fundamento do tratamento diferenciado que se dá ao inimigo está consubstanciado no fato de lhe ser negada a sua própria existência enquanto pessoa, uma vez que este sujeito só é visto sob o ponto de vista de um ser truculento ou perigoso.

Quando o doutrinador Günther Jakobs traz a distinção entre cidadãos e inimigos, o que se pretende expor é a existência de uma categoria de sereshumanos cujos direitos individuais são restringidos, razão pela qual, na concepção do autor, eles perdem a sua identidade enquanto pessoa.

No entanto, não é a redução da quantidade de direitos que anula a condição de pessoa do indivíduo, mas sim o fato de seus direitos serem reduzidos, em razão de eles serem considerados inimigos.

A propósito:

Não é a quantidade de direito de que alguém é privado que lhe anula a condição de pessoa, mas sim a própria razão em que essa privação de direitos se baseia, isto é, quando alguém é privado de algum direito apenas por que é considerado pura e simplesmente como um ente perigoso. ${ }^{34}$

${ }^{34}$ ZAFFARONI, Eugenio Raul. O Inimigo no Direito Penal. $1^{\text {a }}$ ed. Rio de Janeiro: Renavam, 2007, p. 18. 
$\mathrm{Na}$ atualidade, há o entendimento segundo o qual o inimigo é submetido à contenção como indivíduo perigoso, em razão de um estado de necessidade. Isto quer dizer que, só há a privação da liberdade da pessoa, para neutralizar a sua truculência.

Outrossim, se teoriza sobre um direito penal para iguais e outro para estranhos ou inimigos, em que, para os primeiros, destina-se penas retributivas e aos segundos, medidas administrativas, as quais são um misto entre o direito penal e a coerção administrativa direta, haja vista que não respondem à gravidade do fato, mas sim ao direito penal do autor, conforme sua periculosidade positiva.

Ocorre que, esta é uma limitação ao princípio do estado de direito, e ao caráter ressocializador da pena, eis que, o encarceramento é exigido apenas por uma imposição e por uma medida de necessidade.

É imperioso destacar que, a estrita medida de necessidade, por seu turno, é a estrita medida de algo que não tem fim, haja vista que os limites são exercidos por quem detém o poder. Logo, o grau de hostilidade da pessoa sempre será medido através de um juízo de valor subjetivo, que não é outro senão o de quem exerce o poder.

Ou seja, o critério para medir a periculosidade de alguém passa a ser subjetivo, entra-se no campo da arbitrariedade do individualizador do inimigo, no qual invoca uma medida de segurança que nem sempre é necessária.

Tendo em vista isto, abandona-se o critério objetivo que, acertadamente, para medir a periculosidade e o dano do infrator, faz uso do caso concreto e não da possibilidade futura de este ser vir a infringir qualquer tipo de lei, tal qual ocorre no critério subjetivo.

A título de elucidação, o trato desigual entre seres humanos privados de caráter de pessoas, era próprio do Estado Absolutista, na qual se exercia um constante poder de vigilância e, em especial, sobre os que se supunham ser potencialmente daninhos para a hierarquização social. 
Todavia, dentro de um Estado Constitucional, é intolerável a categoria jurídica de inimigo ou de estranho, uma vez que nessa forma de Estado deve haver o processo de libertação da pessoa humana, bem como das formas de opressão, as quais não dependem só do reconhecimento formal de certos direitos individuais, políticos e sociais, mas, especialmente, a vigência de condições de sustentar a dignidade da pessoa humana e respeitar o indivíduo enquanto ser-humano.

No que se refere ao Direito Penal, aplicar o Estado de Direito, significa, sobretudo, dar ao indivíduo o direito de ter as suas garantias fundamentais aplicadas de fato, e não apenas tê-las como normas nominais, razão pela qual destoa do Estado Constitucional a distinção trazida por Günther Jakobs entre inimigo e cidadão.

Por assim ser, o Direito Penal, quando utilizado de forma arbitrária, torna-se uma das mais poderosas armas contra o ser humano, contra os direitos inerentes ao mesmo e, por conseguinte, contra a manutenção do próprio Estado Democrático de Direito.

Afinal, quantas barbáries já se efetuaram sob o manto protetor da legalidade, com o pensamento de que se há a previsão na lei penal, é lícito. Tal pensamento conduziu a inúmeras barbáries, desde os tempos mais remotos até as chacinas dentro de presídios brasileiros, ocorridas a não muito tempo.

Ademais, o modo orientador do Estado de Direito é fundamental para direcionar o poder jurídico na sua tarefa de superação dos defeitos dos Estado de direito reais ou históricos.

Caso haja a entrega dos mecanismos para superar e conter as pulsões autoritárias, o poder jurídico fica privado de qualquer possibilidade de eficácia não somente tática, mas como também estratégica, para conter essa tirania que retira do sujeito a sua forma humana e consequentemente o torno um inimigo. 
A propósito:

Certamente o Estado pode privá-lo de sua cidadania, porém isso não implica que esteja autorizado a privá-lo da condição de pessoa, ou seja, de sua qualidade de portador de todos os direitos que assistem a um ser humano pelo simples fato de sê-lo. ${ }^{35}$

Sucede-se que, a sociedade em um discurso autoritário, simplista e populista, é levada pelos meios de comunicação a ter uma ideologia de repressão e repreensão desses seres ditos daninhos.

Não obstante isto, nesta mesma conjuntura, os políticos com condutas autistas, sancionam leis penais e processuais penais autoritárias, violadoras de princípios e garantias constitucionais.

Ou seja, preveem penas que muitas das vezes não podem ser cumpridas, pois, ou excedem a duração da vida humana ou utilizam nomenclaturas abertas e nebulosas, que podem vir a ser aplicadas de qualquer forma pelo magistrado.

A exemplo disso, o artigo 52 da Lei de Execuções Penais dispõe que estará sujeito ao Regime Disciplinar Diferenciado aquele sob o qual recaiam fundadas suspeitas de envolvimento ou participação, a qualquer título, em organizações criminosas, quadrilhas ou bandos.

O fato de ser utilizada a expressão "a qualquer título", faz com haja o entendimento segundo a qual qualquer ocorrência dentro de uma carceragem, por menor que seja, pode vir a ser motivo para o interno ficar sob a guarda do Regime Disciplinar Diferenciado.

Além disso, a partir do momento que, diuturnamente, há a conversão de todas as penas em coerção direta, chega-se à conclusão de que toda infração faz parte de uma agressão real. Logo, todo e qualquer poder punitivo passa a ser exercido em razão de uma legítima defesa, que nem sempre é real e acaba abrindo brecha para legitimar a tortura.

${ }^{35}$ Ibid. p. 13. 
Ora, não é necessário adotar nenhuma posição radical para enxergar que toda violência deve ser respondida com a não-violência, bem como a diminuição da violência não deve ter como solução o recrudescimento do direito penal. Isto porque, as referidas normas já existem, basta que elas sejam aplicadas de modo correto e humano.

À vista do que foi discorrido neste capítulo, chega-se à conclusão de que a descriminação no exercício do poder punitivo é uma constante derivada de sua seletividade estrutural, conforme preleciona o ilustríssimo doutrinador Eugenio Raul Zaffaroni.

Assim sendo, ao ter uma doutrina que coaduna com essa ideia de direito penal do inimigo e, mais do que isso, torna legítimo o referido conceito, estará se permitindo contraposição ao Estado de Direito e a sua teoria política.

Nesse sentido:

A hipótese de base que procuramos comprovar parte da natureza política da questão colocada e visa a verificar que, no plano da teoria política, é intolerável a categoria jurídica de inimigo ou estranho no direito ordinário (penal ou de qualquer outro ramo) de um Estado constitucional de direito, que só pode admiti-lo nas previsões de seu direito de guerra e com as limitações que lhe são impostas pelo direito internacional dos direitos humanos em seu ramo de direito humanitário (...), levando-se em conta que nem sequer este priva o inimigo bélico da condição de pessoa"36

${ }^{36}$ Ibid. p. 12. 


\section{CONCLUSÃO}

Consoante já assinalado na presente monografia, o direito penal do inimigo é o típico direito penal do autor, no qual se pune os indivíduos não em razão de sua culpabilidade, mas em virtude de sua periculosidade, reprime-se o sujeito pelo que ele é na sua essência, e não pelas suas ações.

Mister ressaltar que, dentre os institutos típicos desse gênero de execução da pena, o que tem maior relevância, bem como importância, é a incomunicabilidade do interno.

Com efeito, os juristas que advogam a tese do direito penal do autor, aduzem que a referida medida tem a finalidade de obstar a comunicação do detento com seu patrono e demais detentos, haja vista que, devido a sua periculosidade, ao deixá-lo conviver com os demais detentos, estar-se-ia colocando em risco a vida, a integridade física ou a liberdade de terceiros.

Em companhia da incomunicabilidade do detento, são, também, de serventia contumaz do Direito Penal do Inimigo as prisões com base em mera suspeita, dispensando-se, muitas das vezes, a autorização judicial, além de serem recorrentes os mecanismos de tortura psicológica e física.

Os direitos e garantias conferidos ao cidadão são completamente negados ao inimigo, age o Estado de modo contrário aos principais preceitos fundamentais, viola-se, com isso, o núcleo rígido da Constituição, qual seja: o princípio da dignidade da pessoa humana no que tange a vedação à tortura.

Neste diapasão, Eugenio Raul Zaffaroni preleciona que:

Nossa tese é que o inimigo da sociedade ou estranho, quer dizer, o ser humano considerado como ente perigoso ou daninho e não como pessoa com autonomia ética, de acordo com a teoria política, só é compatível com um modo de Estado absoluto e que, consequentemente, as concessões do penalismo têm sido, definitivamente, obstáculos absolutistas que a doutrina penal colocou como pedras no caminho da realização dos Estados constitucionais de direito. ${ }^{37}$

\footnotetext{
${ }^{37}$ ZAFFARONI, E. Raul. Op. cit., p. 12.
} 
Outro efeito da despersonalização do inimigo apreciada por Jakobs Günther é a utilização de mecanismos que devassam não só a vida íntima do suspeito, mas, também, na mesma medida, assolam terceiras pessoas que integram o seu círculo de relações pessoais, indo de encontro ao preceito fundamental de que a pena não pode passar da pessoa do apenado, conforme disposto no art. 5, XLV da Constituição Federal de 1988 (“CFRB/1988”).

Em um Estado Democrático de Direito e, portanto, garantidor da dignidade do ser humano, não pode haver a possibilidade de destituir o status de pessoa de qualquer indivíduo, ou seja, ninguém pode ser classificado como não-pessoa.

Ademais, não se pode esquecer que um dos três fundamentos da República Federativa do Brasil é a dignidade da pessoa humana, a qual se encontra expressamente positivada na CFRB/1988, em seu artigo $1^{\circ}$, inciso III.

Dessa forma, todos os princípios que regem o ordenamento jurídico brasileiro devem se basear no respeito à pessoa humana, haja vista que esta funciona como princípio constitucional geral.

Ou seja, constitui o núcleo essencial intangível dos direitos fundamentais, razão pela qual, no caso da execução penal e dos castigos nela previsto, deve a dignidade ser interpretada como regra e não como princípio, já que a tortura é vedada no ordenamento jurídico brasileiro.

Nesse sentido, deixar de conferir a certos indivíduos os direitos e garantias assegurados pela nossa carta política, significa romper com os ditames fundamentais do Estado Democrático de Direito, abalando in totum a sua estrutura.

A propósito:

(...) as penas previstas são desproporcionalmente altas: especialmente, a antecipação da barreira de punição não é considerada para reduzir, correspondentemente, a pena cominada. (...) determinadas garantias processuais são relativizadas ou 
inclusive suprimidas. (...) há a flexibilização dos princípios políticocriminais e as regras de imputação. ${ }^{38}$

Dito isto, não é novidade que a flexibilização das garantias individuais e das regras de imputação estão em consonância com o que almeja a grande parcela da sociedade e do poder público, isto é, o recrudescimento do Direito Penal, em conjunto os discursos de emergência para conter os sujeitos daninhos para que haja a mitigação do sentimento de insegurança social.

Nesse sentido, segundo entendimento de Salo de Carvalho:

É possível diagnosticar a gradual sobreposição, através dos discursos de emergência, do modelo de hiperpunibilidade do Estado Penal ao romântico escopo ressocializador presente nas políticas públicas do Estado Social. E se no Brasil o Estado Social é experiência não vivida, distante da realidade das pessoas e presente apenas nos longínquos discursos do (s) poder (es), o incremento da punição tende a ser absolutamente rústico, pautado numa ritualística de distribuição de martírios focalizada na segregação/contenção dos indesejados. ${ }^{39}$

Ao se aplicar um Direito Penal de urgência e demasiado amplo, causase insegurança jurídica, carece-se de eficácia prática e desperta-se um sentimento de impunidade generalizado na sociedade.

À visto disso, ao inimigo, não são previstos, no curso do processo, diversos direitos que são conferidos aos cidadãos, tais quais o acesso aos autos do inquérito policial, o direito de solicitar a prática de provas, de assistir aos interrogatórios, de se comunicar com seu advogado e etc.

O ideal trazido a lume é o de que o processo contra o inimigo jamais poderia denominar-se "persecução penal", mas sim procedimento de guerra, haja vista que o único objetivo desse modelo de processo penal é a eliminação dos sujeitos ditos inimigos da sociedade.

\footnotetext{
${ }^{38}$ GÜNTHER, Jakobs. Op. Cit. p. 90/92.

39 CARVALHO, Salo de. Disponível em: $\langle$ https://www.defensoria.sp.def.br/dpesp/Repositorio/30/Documentos/273.pdf $\rangle$. Acesso em 5 out. 2017.
} 
No que tange ao Regime Disciplinar Diferenciado ("RDD”), instituído no Brasil devido ao avanço das organizações criminosas e da incapacidade do poder público em gerir seus próprios detentos, vê-se que o referido instituto seleciona determinada classe de indivíduos e os isola, pondo-se, com isso, fim ao ideal de ressocialização, haja vista que o único objetivo é tão somente retributivo.

Será nessa mesma perspectiva que haverá similitudes entre os ideais do Direito Penal do Inimigo e o "RDD", haja vista que aquele é pautado no direito prospectivo e não retrospectivo, razão pela qual se pune antecipadamente os inimigos por fatos que ainda não ocorreram.

A propósito:

Qual o fim político do castigo? O terror que imprimem nos corações inclinados ao crime. Todavia, que se deve pensar das torturas, esses suplícios secretos que a tirania emprega na obscuridade das prisões e que se reservam tanto ao inocente como ao culpado? Importa que nenhum delito conhecido fique impune; mas nem sempre é útil descobrir o autor de um delito encoberto nas trevas da incerteza. Um crime já cometido, para o qual já não há remédio, só pode ser punido pela sociedade política para impedir que os outros homens cometam outros semelhantes pela esperança da impunidade. Se é verdade que a maioria dos homens respeita as leis pelo temor ou pela virtude, se é provável que um cidadão prefira segui-las, a violá-las, o juiz que ordena a tortura expõe-se constantemente a atormentar inocentes. ${ }^{40}$

Dessa forma, o regime disciplinar diferenciado, legitimado por vários setores da comunidade jurídica, fez nascer um grande abismo entre os presos portadores de direitos e os inimigos. Em relação a estes últimos, o Estado deixa de ter qualquer responsabilidade social, voltando seus mecanismos para combater permanentemente sua forma de vida perigosa.

\footnotetext{
${ }^{40}$ BECCARIA, Cesare. Op. cit., p. 20.
} 
Ante ao exposto nessa monografia, o sistema penal brasileiro não assimilou, por certo, todas as características que identificam o direito penal do inimigo, como a incomunicabilidade do preso, utilização de julgadores e etc.

No entanto, não se pode olvidar que, ao introduzir o RDD, incorporouse determinados aspectos típicos de um direito penal do autor, que seleciona os inimigos do sistema, procurando inabilitá-los e eliminá-los. 


\section{REFERÊNCIAS BIBLIOGRÁFICAS}

BATISTA, Nilo. Introdução Crítica ao Direito Penal brasileiro. $5^{\mathrm{a}}$ ed. Rio de Janeiro, Renavam, 2001.

BECCARIA, Cesare. Dos Delitos e Das Penas. São Paulo, Edipro de Bolso, 2016.

CARVAlHO, Luis Gustavo Castanho. Processo Penal e Constituição. Princípios Constitucionais do Processo Penal. $6^{\mathrm{a}}$ ed. São Paulo, Saraiva, 2014.

CARVALHO, Salo de. Disponível em: <https://www.defensoria.sp.def.br/dpesp/Repositorio/30/Documentos/273.p df>. Acesso em 5 out. 2017.

CARVALHO, Salo e WUNDERLICH, Alexandre. O Suplício de Tântalo: a Lei 10.792/03 e a Consolidação da Política Criminal do Terror. Disponível em <https://www.ibccrim.org.br/boletim_artigos/163-134-

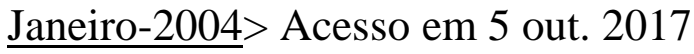

CARVAlHO, Salo de. Crítica à Execução Penal: Doutrina, Jurisprudência e Projetos Legislativos. $2^{\mathrm{a}}$ ed. Rio de Janeiro, Lumen Juris, 2007.

DOTTI, René Ariel. Movimento Antiterror e a Missão da Magistratura. $2^{\mathrm{a}}$ ed. Curitiba, Juruá, 2005.

FERRAJOLI, Luigi. Derechos y Garantías. La ley de más débil. Madrid, Trotta, 1999. 
FOUCAULT, Michel. Vigiar e Punir. História da Violência nas Prisões. 39a ed. Rio de Janeiro, Editora Vozes, 1997.

FOUCAULT, Michel. Microfísica do Poder. Disponível em: <http://petletras.paginas.ufsc.br/files/2017/03/foucault-microfisica-dopoder.pdf>Acesso em 5 out. 2017.

GÜNTHER, Jakobs. El Enemigo Tiene Menos Derechos. Disponível em <http://www.lanacion.com.ar/826258-el-enemigo-tiene-menos-derechosdice-gunther-jakobs.> Acesso em 5 out. 2017.

JAKOBS, Günther. MELIA, Manuel Cancio. Direito Penal do Inimigo. Noções e Críticas. $6^{\mathrm{a}}$ ed. Porto Alegre: Livraria do Advogado, 2012.

JÚNIOR, Miguel Reale. Novos Resumos do Sistema Criminal. $1^{\mathrm{a}}$ ed. Rio de Janeiro, Forense, 1983.

MIRABETE, Julio Fabbrini. Execução Penal. 9ª ed. São Paulo, Atlas, 2000.

PACELLI, Eugenio. Curso de Processo Penal. 19ª ed. São Paulo, Atlas, 2015 .

ROIG, Rodrigo Duque Estrada. Execução Penal. Teoria Crítica. $3^{a}$ ed. São Paulo, Saraiva, 2017.

ROIG, Rodrigo Duque Estrada. Direito e Prática Histórica da Execução Penal no Brasil. $1^{\mathrm{a}}$ ed. Rio de Janeiro, 2005.

SARLET, Ingo Wolf. Dignidade da Pessoa Humana e direitos fundamentais na Constituição Federal. $2^{\mathrm{a}}$ ed. Porto Alegre, Livraria do Advogado, 2002. 
SARMENTO, Daniel A. A ponderação de interesses na Constituição Federal. $1^{\text {a }}$ ed. Rio de Janeiro, Lumen Juris, 2002.

STF, HC nº 70.3089, Rel. Ministro Sydney Sanches, Brasília 23 jun. 1994.

STF, HC nº 70.3089, Rel. Ministro Sydney Sanches, Brasília 23 jun. 1994.

STJ, Habeas Corpus $n^{\circ}$ 40.300, Rel. Ministro Arnaldo Esteves Lima, Brasília, 7 jun. 2005.

ZAFFARONI, Eugenio Raúl. O Inimigo do Direito Penal. $1^{\text {a }}$ ed. Rio de Janeiro, Renavam, 2007.

<http://www.planalto.gov.br/ccivil_03/leis/L7210.htm > Acesso em 5 out. 2017 